\title{
GNAI2 Gene
}

National Cancer Institute

\section{Source}

National Cancer Institute. GNAI2 Gene. NCI Thesaurus. Code C24436.

This gene plays a role in signal transduction and neurotransmission. 